\title{
Patterns of Ice Formation and Movement in Blackcurrant
}

\author{
John Carter \\ Departments of Horticultural Science and Plant Biology, University of \\ Minnesota, St. Paul, MN 55108
}

Rex Brennan ${ }^{1}$

Scottish Crop Research Institute, Invergowrie, Dundee DD2 5DA, Scotland

Michael Wisniewski

U.S. Department of Agriculture, Agricultural Research Service, 45 Wiltshire

Road, Kearneysville, WV 25430

Additional index words. freezing injury, supercooling, deacclimation, Ribes nigrum

\begin{abstract}
Ice formation and movement in stems, leaves, and flowers of blackcurrant were observed by infrared video thermography. Stem sections bearing leaves and racemes were cooled slowly to as low as $-6.4^{\circ} \mathrm{C}$ and allowed to freeze without artificial nucleation. Ice formed in stems first, then moved from stems into leaves and racemes. Patterns of ice movement were complex and depended upon the temperature of the initial nucleation event. Individual flowers froze between -1.6 and $-5.5^{\circ} \mathrm{C}$. Survival of flowers after a cooling treatment depended upon whether they froze and the amount of freezing that occurred in the peduncles to which they were attached. Some flowers survived the initial freezing treatments but later died because of peduncle damage. Movement of ice from stems into peduncles sometimes was observed to occur in discrete steps, separated by time and temperature. Several independent freezing events were often observed in a peduncle, rather than one continuous event. Pedicels attached to frozen peduncles often remained supercooled for several minutes to over an hour before freezing. No consistent pattern was evident during freezing of individual flowers in an inflorescence. The range of temperature over which flowers in a single inflorescence froze was in some instances over $4^{\circ} \mathrm{C}$. Both mature and immature flowers supercooled. Barriers to movement of ice appeared to exist at certain anatomical junctions within the plant, notably where the peduncle of an inflorescence attaches to a stem and where a flower pedicel joins a peduncle. The time required for ice to pass through these barriers was inversely related to the degree of supercooling that had occurred prior to freezing.
\end{abstract}

Blackcurrants flower in early spring, and freezing damage can limit production of this crop unless freezing-tolerant cultivars are grown. In previous work (Carter et al., 1999), freezing of detached flowers from three cultivars of blackcurrant revealed no significant genotypic difference in tolerance, even though field plantings of the cultivars exhibited dramatic differences in survival following spring freezes (Dale, 1981, 1987). Genotypic differences in the cold hardiness of whole plants have been exploited by breeders for developing genotypes combining hardiness with other

Received for publication 1 May 2000. Accepted for publication 28 Feb. 2001. Support from the Scottish Office Agriculture, Environment and Fisheries Dept., is gratefully acknowledged. Part of R.B.'s contribution to the work was made while he held the Minnesota Landscape Arboretum Land-Grant Chair for Research. Support from the endowment to this Chair is gratefully acknowledged. This paper is a contribution from the Minnesota Agricultural Experiment Station, Journal Series Article Number 981210053. The cost of publishing this paper was defrayed in part by the payment of page charges. Under postal regulations, this paper therefore must be hereby marked advertisement solely to indicate this fact.

${ }^{1}$ To whom reprint requests should be addressed. E-mail address: rbrenn@scri.sari.ac.uk desirable attributes (Brennan, 1996). The physiological basis of the genotypic differences in freezing tolerance of intact floral racemes of blackcurrant is unclear.

To avoid artifacts while examining freezing events in vivo requires the use of noninvasive methodologies. Freezing in blackcurrant flowers was visualized in vivo using spin-echo nuclear magnetic resonance spectroscopy by Brennan et al. (1997), although the ability of this technique to record ice movement in real time, as opposed to the visualization of subsequent damage, is limited. The use of infrared video thermography in controlled environment facilities allows a comprehensive view of the freezing process, including initial freezing events as well as subsequent propagation of ice (Fuller and Wisniewski, 1998; Wisniewski et al., 1997). Previous observations of intact plants subjected to freezing treatments suggested that flowers might survive spring freezes by supercooling (Carter et al., 1999). While this work demonstrated that detached flowers can supercool to at least -9 ${ }^{\circ} \mathrm{C}$, it did not answer the question of whether flowers on intact plants supercool. The freezing of supercooled water within plant tissues has been correlated with cellular injury (Ashworth et al., 1983; Lindstrom and Carter,
1983), so the degree to which flowers on intact plants can supercool could be crucial to their potential survival.

The present work was undertaken to examine the freezing process in intact, flowering shoots of blackcurrant to determine patterns of ice propagation and whether individual flowers can supercool. Knowing more about the propagation of ice into and within racemes might suggest new cultural practices or new breeding strategies to minimize low-temperature injury in blackcurrant and other woody plants.

\section{Materials and Methods}

Cuttings (10-20 cm in length) were taken from mature blackcurrant plants maintained in the field at the Horticultural Research Center (HRC) in Excelsior, Minn. Cultivars used were 'Blackdown' (14 cuttings), 'Ojebyn' (17 cuttings), 'Ben Tirran' (6 cuttings), 'Ben Sarek' ( 6 cuttings), 'Ben Alder' (3 cuttings), and 'Ben Lomond' (10 cuttings). All results were detected in more than one cultivar.

For the experiments carried out in 1998, cuttings were kept moist at $0{ }^{\circ} \mathrm{C}$ and transported within $18 \mathrm{~h}$ of removal from the field to Kearneysville, W. Va. For the experiments carried out in 1999, cuttings were taken immediately from the HRC to laboratory facilities in St. Paul, Minn. Cut ends were freshly trimmed, inserted in wet floral foam, and held at $4{ }^{\circ} \mathrm{C}$ until analysis.

Ice nucleation and propagation. Ice nucleation and propagation were monitored by infrared thermography, using an Inframetric model 760 Radiometer (Inframetrics, Billerica Mass.). This instrument detects differences in temperature of $0.1^{\circ} \mathrm{C}$ or less. Water's large heat of fusion leads to a sharp rise in temperature of supercooled plant tissue as it freezes, making it possible with this methodology to observe freezing of small amounts of tissue water. Freezing events are visualized as changes in color (if recorded in color) or in shades of gray (if recorded in black-and-white). Before a plant tissue freezes, its temperature is very close to that of its surroundings, which means the image is almost invisible. The degree of change in color or shade of gray and the length of time required for the tissue temperature to return to isothermal are both indicators of the amount of tissue water that freezes in a particular freezing event. Once the heat of fusion is dissipated, the tissue once again becomes isothermal, requiring the complete freezing process to be viewed if the processes of ice nucleation and propagation are to be understood. The infrared video camera was mounted horizontally in a temperature-programmable cabinet (model T20S; Tenney Environmental Test Chamber; Lunaire, Williamsport, $\mathrm{Pa}$.). Cuttings were left in floral foam, placed in the cabinet, held at 0 to $1^{\circ} \mathrm{C}$ for 40 to $60 \mathrm{~min}$, and then cooled at $5^{\circ} \mathrm{C} / \mathrm{h}$ to the final test temperature, which varied from -3.9 to $-6.4^{\circ} \mathrm{C}$. Ice formation and propagation were observed in real time and images recorded on videotape. For the 1999 experiments, the camera was transported to Minne- 
sota and set up in an identical temperatureprogrammable cabinet.

Assessment of injury. The experiments in which injury was assessed were carried out in 1999, in Minnesota, with the same camera, in an identical temperature-programmable cabinet. The cabinet was programmed to cool at $5{ }^{\circ} \mathrm{C} / \mathrm{h}$ to $-5^{\circ} \mathrm{C}$, remain at $-5^{\circ} \mathrm{C}$ for $1 \mathrm{~h}$, and warm to $4{ }^{\circ} \mathrm{C}$ at $3{ }^{\circ} \mathrm{C} / \mathrm{h}$. Samples were then stored at $4{ }^{\circ} \mathrm{C}$ for at least $24 \mathrm{~h}$, then moved to ambient temperature for 24 to $48 \mathrm{~h}$, and injury was determined by visual assessment. Sections were kept well-watered throughout an experiment.

\section{Results}

Ice formation and propagation. In 22 cuttings (including at least one cutting from each of the 6 cultivars used in the study) containing stems, leaves, and flowers, freezing was always initiated in the woody stem. However, the stem tissues (xylem ray parenchyma, cortex, cambium, etc.) that froze first could not be determined. In each cutting, ice propagated into leaves within seconds after the ice front in the stems reached leaf petioles. Ice also formed in stem tissue before leaf or floral tissue in two experiments ('Ojebyn', 2 cuttings per experiment) in which stem sections were misted prior to cooling to mimic a freezing event in which plant surfaces were wet with dew.

The temperature at which nucleation occurred was dependent on the water status of the stem sections, as has been previously observed (Wisniewski et al., 1997). Stems that had been air-dried prior to cooling ('Blackdown', 3; 'Ben Tirran', 4; 'Ben Sarek', 3 cuttings) supercooled to a greater degree than did fully hydrated stems. The mean nucleation tem- perature (MNT) was $-1.1 \pm 0.5^{\circ} \mathrm{C}(\mathrm{n}=23)$ for fully hydrated cuttings, and $-2.7 \pm 0.5^{\circ} \mathrm{C}(\mathrm{n}=$ 10) for cuttings dried in air from 1 to $3 \mathrm{~h}$.

After ice nucleation in cuttings, regardless of whether fully hydrated or air dried, the ice front moved almost immediately from stem to attached leaves (Fig. 1a-c).

Ice formation in flowers. Flowers supercooled even though ice was present in the stem to which the inflorescence was attached. In Fig. 1 , for example, even though all stems and most leaves were frozen at $-1.4{ }^{\circ} \mathrm{C}$, some flowers remained supercooled to almost $-5^{\circ} \mathrm{C}$.

Ice propagation within peduncles. Multiple freezing events were observed within a single peduncle in seven separate experiments involving at least one cutting of five cultivars ('Blackdown', 3; 'Ojebyn', 2; 'Ben Alder', 1; 'Ben Sarek', 1; 'Ben Lomond', 2 cuttings). Five freezing events were observed in 1 peduncle, four in another, 3 in three peduncles, 2 in four peduncles, and 1 in one peduncle. Each freezing event appeared to be independent of and separated in time and temperature from the others. Five separate freezing events were recorded in one 'Ben Lomond' peduncle; three of these are shown in Fig. 2. The first four of these freezing events each released only a small amount of heat, which was largely dissipated prior to the subsequent freezing event. For example, when the image in Fig. 2e was captured the heat liberated in the first freezing event had dissipated and the peduncle was once again invisible to the infrared camera. In Fig. 2f, the second of the individual peduncle freezing events had just been completed. This sequence was repeated two more times. Each of these four freezing events began at the base of the peduncle, indicating that it was nucleated by contact with ice in the stem and not by contact with ice present in the peduncle from prior freezing events.

In all peduncles in which multiple freezing events were observed, the final freezing event differed from the previous freezing events in two ways. First, it involved much more water than any of the prior events. Using the 'Ben Lomond' cutting as an example again, the heat released by the final freezing event in the peduncle had not dissipated when Fig. $2 \mathrm{~g}$ was captured, several minutes after the entire raceme had frozen, showing that the amount of water frozen in the final event was much larger than that frozen in any of the first four events. Second, the final freezing event was not initiated at the base of the peduncle; it could begin at any point.

A flower and its pedicel can supercool when ice is present in the peduncle to which the flower's pedicel is attached. In all cultivars examined, flowers attached to a frozen peduncle could remain supercooled for a considerable time, as shown in Fig. 3.

Ice propagation within pedicels. Two separate freezing events were commonly observed in pedicels of individual flowers of all cultivars. Pedicels often remained supercooled after ice had formed in the peduncle to which they were attached. The initial freezing event in a pedicel often involved only a small quantity of water, since the liberated heat of fusion dissipated within seconds. This heating event always began at the juncture of the pedicel with its peduncle and moved quickly to the base of the flower. After freezing occurred within the pedicel, the attached flower would begin to freeze. In Fig. 4, the complexity of freezing of an individual pedicel and attached flower is summarized.
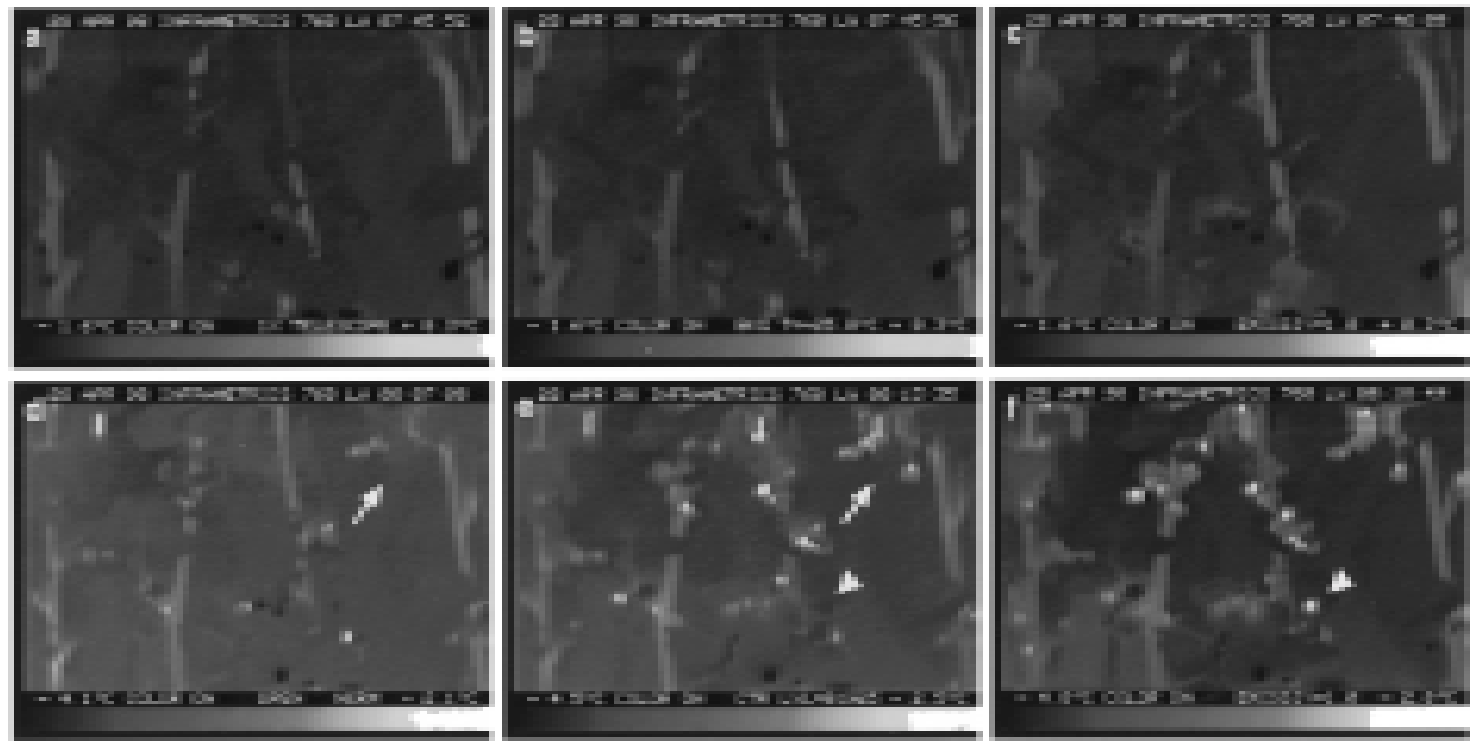

Fig. 1. Ice formation in blackcurrant stems, leaves, and flowers. (a) A few seconds prior to this image, at $-1.4{ }^{\circ} \mathrm{C}$, ice nucleation occurred in stem 3 (counting from left) beyond the field of view at the bottom of the screen; at the time the image was captured ice had propagated part-way through the stem. Ice had already formed in the other three stems. Ice propagated from the cut end to apex in all stems. (b) Ice moved $\approx 5 \mathrm{~cm}$ farther through stem 3 in the $4 \mathrm{~s}$ between (a) and (b). (c) Still at the same temperature, $13 \mathrm{~s}$ later, ice had moved into three leaves on stem 3 . (d) At $-4.0^{\circ} \mathrm{C}$, a few flowers had frozen (indicated by bright spots). The arrow points to a cluster of still nonfrozen flowers. (e) At $-4.4^{\circ} \mathrm{C}$ several flowers in the region pointed out in (d) had now begun to freeze. The arrowhead marks a flower that was still supercooled. (f) The flower marked by the arrowhead in (e) had begun to freeze, after having supercooled to $-4.8^{\circ} \mathrm{C}$. 

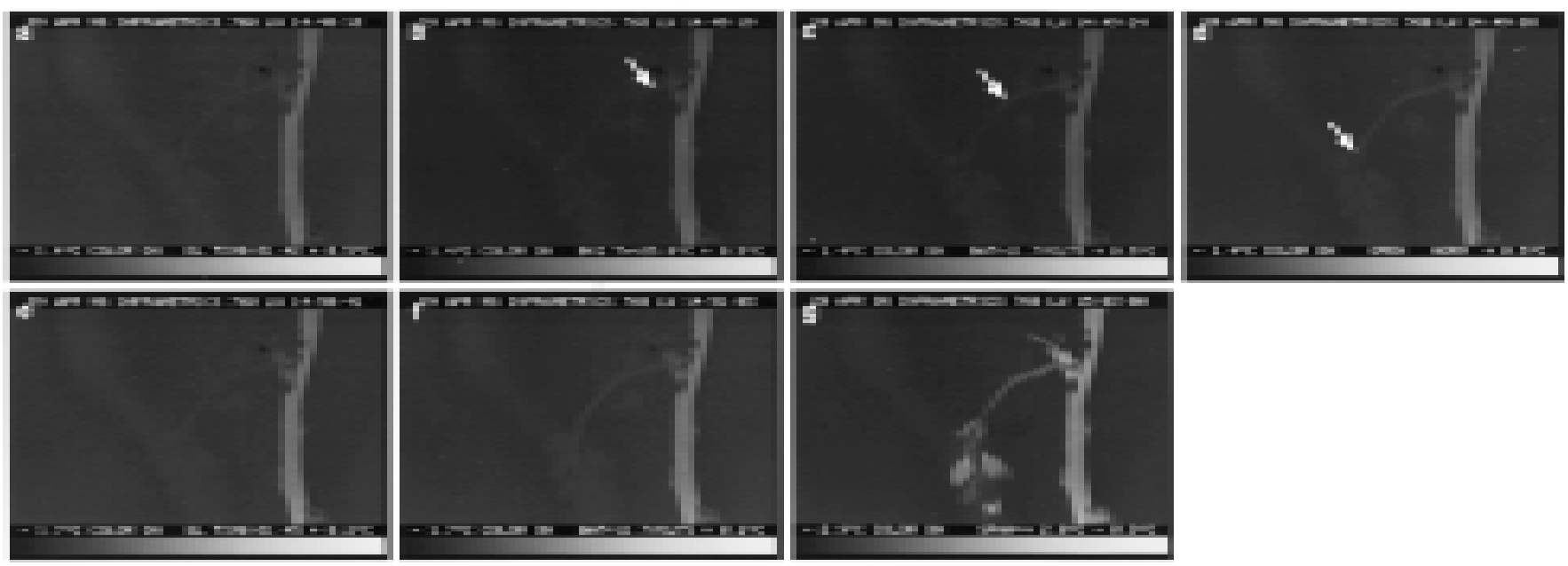

Fig. 2. Multiple freezing events in the peduncle of a blackcurrant floral raceme. Leaves and other racemes were trimmed away to allow an unrestricted view. The peduncle was $\approx 5 \mathrm{~cm}$ in length. (a) The chamber temperature was $-1.4^{\circ} \mathrm{C}$; the stem had frozen but ice had not yet moved into the peduncle. (b) The arrow marks the beginning of a freezing event in the peduncle. (c) The ice front had moved about halfway through the peduncle, within $5 \mathrm{~s}$. (d) The ice front had reached the end of the peduncle within about $10 \mathrm{~s}$ after the freezing event began. (e) The heat of fusion associated with the freezing event shown in (b-d) had dissipated, so the temperature of the peduncle was the same as the background temperature, rendering it invisible to the infrared camera. (f) A second freezing event in the same peduncle had just finished; like the first, it initiated where the peduncle was attached to the stem and progressed steadily to the end of the peduncle in about $10 \mathrm{~s}$. (g) The peduncle was completely frozen, as were several flowers attached to it.

Fate of supercooled flowers that froze. In eight experiments in which flower health was noted following a freeze-thaw cycle ('Ben Lomond', 6 cuttings; 'Blackdown', 5 cuttings), a direct correlation was observed between the number of flowers that froze and the number of flowers that were dead $24 \mathrm{~h}$ later. Flower freezing was followed using the infrared camera and color photographs taken after the recovery period. One of these experiments is depicted in Fig. 5; the frozen flowers marked in Fig 5a were identical with the dead flowers marked in Fig. 5b.

Freezing of floral tissue on cuttings on which stems supercooled significantly. In the 10 air-dried cuttings, with MNT of $-2.7^{\circ} \mathrm{C}$, after ice formed it moved from stem into peduncle seconds after the ice front reached the peduncle. As the ice front moved through the peduncle all tissue water appeared to freeze. Freezing of pedicels could not be distinguished from freezing of the peduncle to which the pedicels were attached. Flowers in the raceme froze seconds later.

Table 1 provides a summary of our observations of freezing events in blackcurrant tissues.

\section{Discussion}

While undergoing rapid growth in the spring, and especially while flowering, most horticultural crops are vulnerable to freezing damage. Temperatures just a few degrees below the freezing point of water can be devastating when plants are completely deacclimated. Notwithstanding this sensitivity, many crops can tolerate temperatures a few degrees below $0{ }^{\circ} \mathrm{C}$ during these periods. A better understanding of ice nucleation and propagation in woody horticultural crops is a worthwhile goal, because it may clarify whether survival

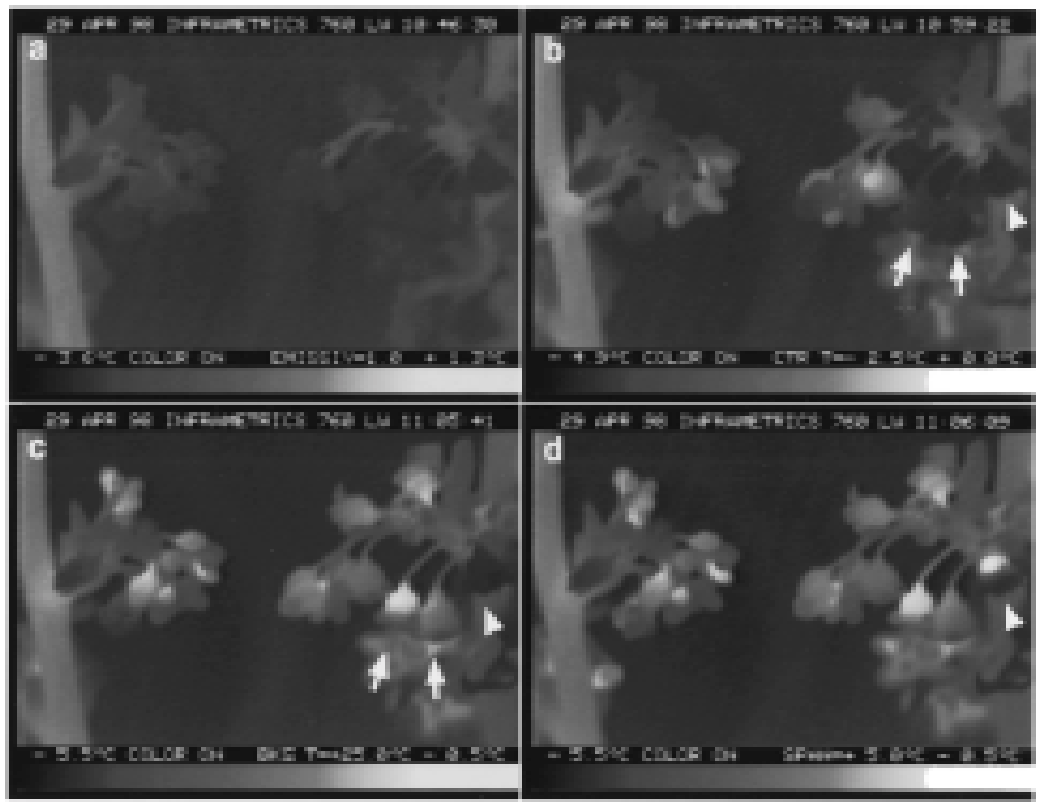

Fig. 3. Supercooling of blackcurrant flowers and pedicels. A close-up view of two racemes. (a) At $-3.6^{\circ} \mathrm{C}$ no flowers had frozen although both stems and peduncles were frozen. (b) At $-4.9^{\circ} \mathrm{C}$ most flowers had frozen but on the right-hand stem three flowers remained supercooled. (c) At $-5.5^{\circ} \mathrm{C}$ the two flowers marked by arrows in (b) had begun to freeze, but the one marked by the arrowhead in (b) remained supercooled. The pedicels of the two flowers marked by arrowheads can also be seen, indicating that they had also recently frozen. (d) After an additional $0.5 \mathrm{~min}$, still at $-5.5^{\circ} \mathrm{C}$, the flower marked by the arrowhead in (b) and (c) had begun to freeze.

is based on mechanisms of tolerance or avoidance, or a combination of both. This information may lead to more effective cultural practices for avoiding freezing damage, as well as to improved breeding strategies for the development of freezing-tolerant cultivars. Blackcurrant is an excellent model system for such study, as it flowers quite early in the plant's development, is easily propagated and maintained, and field-grown material shows genotypic variation in freezing tolerance.
Detached blackcurrant flowers have an $\mathrm{LT}_{50}$ of about $-5^{\circ} \mathrm{C}$, independent of stage of development, provided ice nucleation occurs close to $0{ }^{\circ} \mathrm{C}$ (Carter et al., 1999). In the present work, however, we show that ice nucleation rarely, if ever, occurs close to $0{ }^{\circ} \mathrm{C}$ in flowers on intact plants, even if ice is present in stems adjacent to them. Previous observations (Carter et al., 1999) led us to hypothesize that, during a mild freeze, blackcurrant flowers may avoid damage by supercooling. Infrared video ther- 


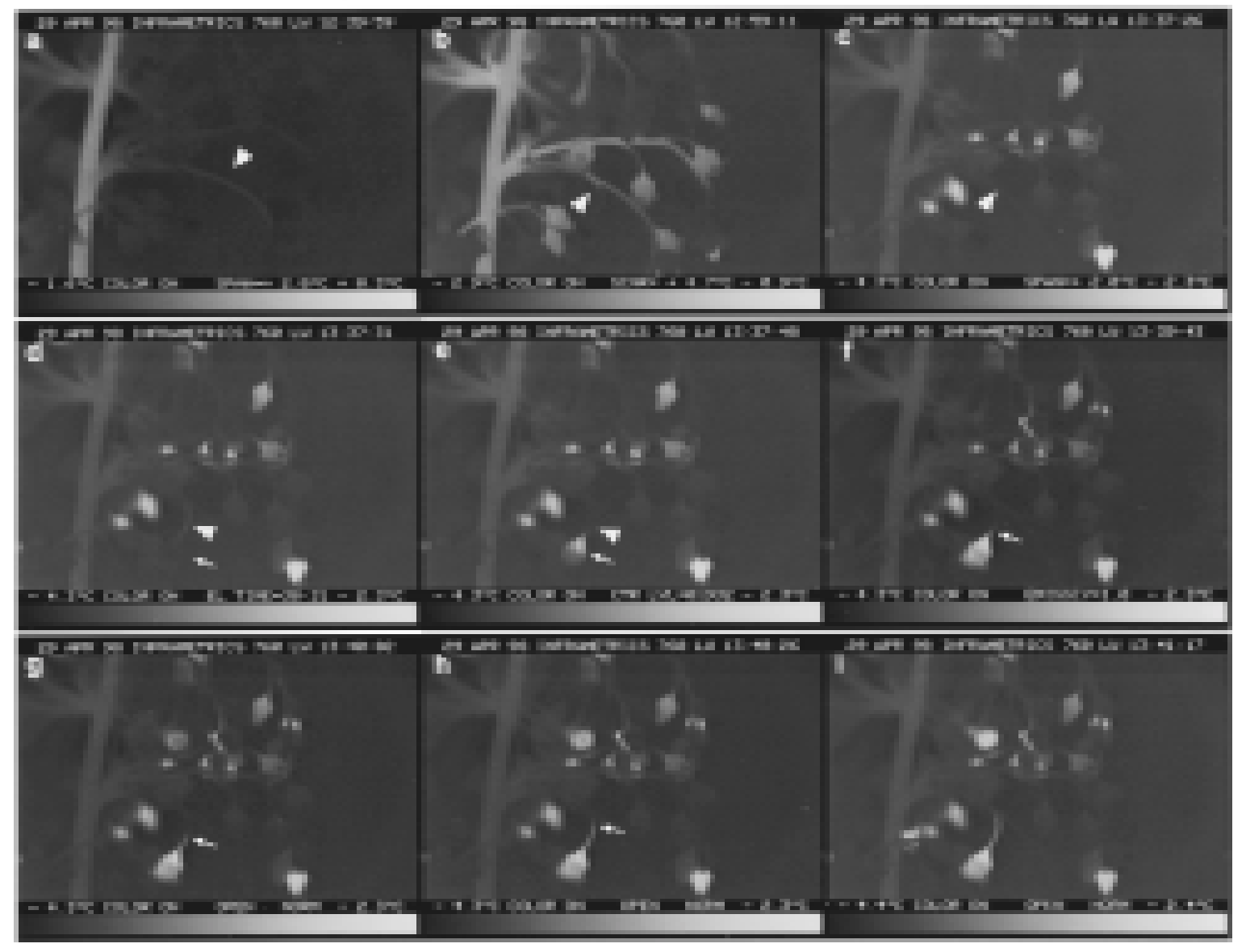

Fig. 4. Multiple freezing events in a blackcurrant pedicel, and the mode of freezing of a flower. (a) Ice first formed at $-1.6^{\circ} \mathrm{C}$ in the peduncle to which the pedicel under observation was attached. (b) At $-2.9^{\circ} \mathrm{C}$, the peduncle was completely frozen; the arrowhead marks the juncture of the pedicel with the peduncle. (c) The peduncle was invisible at $-4.3^{\circ} \mathrm{C}$ because the heat liberated when water froze had dissipated, and its temperature was no longer higher than the background temperature. The arrowhead is in the same location as in b, marking the juncture of the pedicel under observation. (d) Ice had just propagated through the pedicel (arrowhead). The arrow points to the flower subtending the pedicel, which was still supercooled. (e) The base of the flower (arrow) had begun to freeze $18 \mathrm{~s}$ later and the heat from the pedicel freezing event had dissipated, rendering it invisible (arrowhead). (f) A second freezing event had begun in the pedicel, at the base of the flower (arrow). Ice had moved from the base of the flower into the petals. (g) After another $19 \mathrm{~s}$ the ice front in the pedicel had moved roughly $1 / 3$ of the length of the pedicel (arrow). (h) After an additional $24 \mathrm{~s}$ the ice front was roughly $2 / 3$ through the pedicel. (i) The full length of the pedicel had frozen; over $90 \mathrm{~s}$ had elapsed since the beginning of the second freezing event in the pedicel, but the heat released from this event had not dissipated.

mographic results presented here support this hypothesis.

Although the cooling rate used in our experiments, $5{ }^{\circ} \mathrm{C} / \mathrm{h}$, is more rapid than most natural rates, it does not detract from the conclusions we reach. Both the tissues in the blackcurrant raceme and their heat capacities are quite small, and they come into thermal equilibrium rapidly. This is demonstrated by the video recordings; if the cooling rate were too rapid to allow cooling of the racemes to keep pace, they would become warmer than the background, and the temperature differential would increase with time. This did not occur. Thus supercooling within stems was not promoted by the cooling rate in our experiments. In many cases, when the stems were fully hydrated, freezing began above $-1.0^{\circ} \mathrm{C}$. For experiments in which injury was assessed, the warming rate was also controlled. We chose $3{ }^{\circ} \mathrm{C} / \mathrm{h}$ for the warming rate, slower than the cooling rate so as to ensure that what injury we observed would be from freezing of the supercooled flowers, not from warming and thawing.

The Tenney freezing unit uses air circulation to minimize spatial temperature gradients. Conditions during a cooling run thus resembled those on a cold night with a moderate breeze. Concern that drying of plant tissue by the circulating air might confound our results was alleviated by the two misting experiments, in which plant tissue was thoroughly misted prior to the beginning of the cooling regime. Water spots on the tissue were visible on the videotapes, since evaporative cooling rendered them colder than background (data not shown), indicating that the hydration status of the plant tissues remained high during the cooling regime. The freezing behavior of these tissues could not be distinguished from that of tissues in other experiments, indicating that drying due to air circulation did not confound our results.

Ice propagation through floral tissues is complex. Ice does not simply form at the distal end of a blackcurrant raceme and move to the proximal end. Water in some regions in the raceme freezes quickly, while that in other regions may remain supercooled even though separated by only fractions of a millimeter from ice in adjacent tissues. As previously reported by Wisniewski et al. (1997) the rate of ice propagation depends upon the temperature at which ice initially forms in the raceme, i.e., the degree of supercooling, as well as upon the structure of the tissue. As yet, it is impossible to predict which flowers will supercool and which will freeze, whether the peduncle will be lethally damaged or will survive, and thus, which flowers on a given plant will survive a given freeze.

The work of Brennan (1991) and Dale (1987) on freezing of blackcurrant flowers on intact plants suggested that flowers became increasingly more sensitive to freezing damage as they opened, so that the youngest flowers were more tolerant than older ones. This may be a result of the tightly-closed nature of the smallest flowers, or deacclimation effects. Flower maturity increases from the proximal to the distal end of the raceme, but variation in freezing tolerance due to maturity is not reflected in the apparently random pattern of freezing.

After ice has formed in stems and leaves it then moves into floral tissue. One interpretation of the multiple nucleation and propagation events sometimes observed is that xylem bundles in a peduncle can freeze in separate events. The rapid and steady propagation of an ice front through a peduncle, as illustrated in 


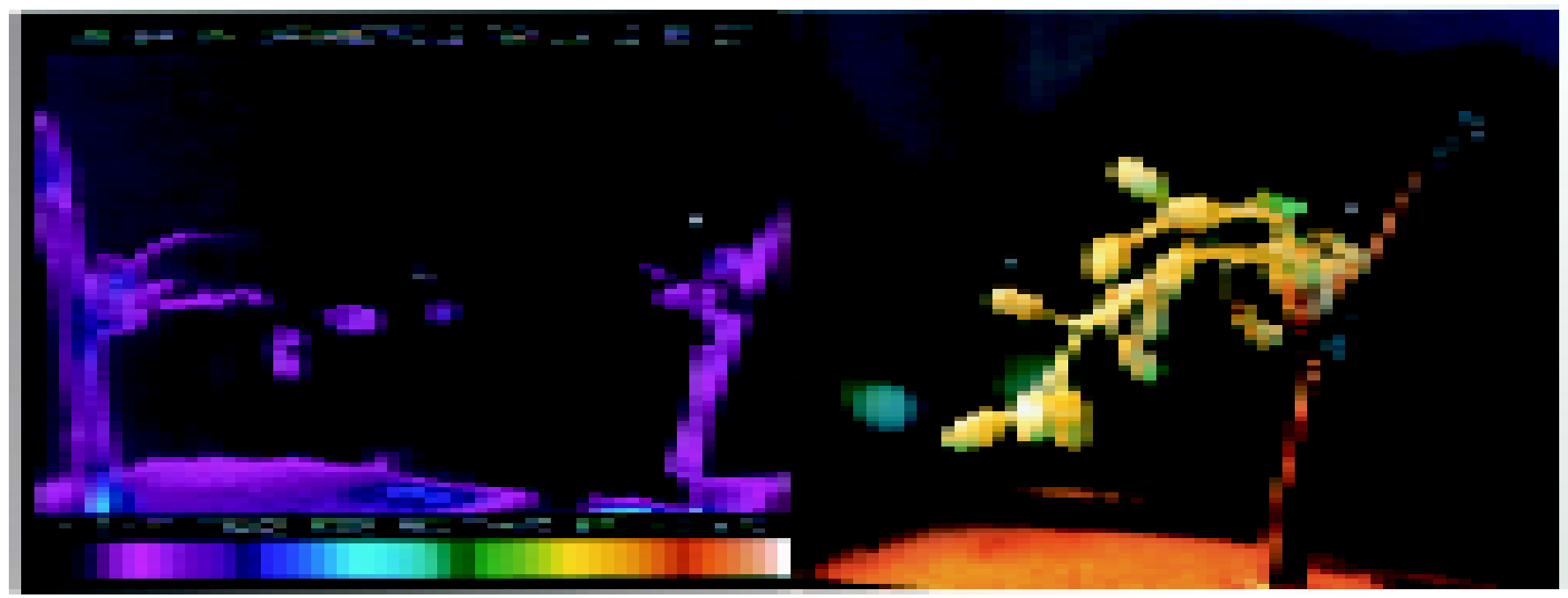

Fig. 5. Freezing of blackcurrant flowers and subsequent consequences. (a) Infrared image in which arrows denote freezing flowers; (b) a photograph taken $24 \mathrm{~h}$ after completion of the experiment in which the same flowers appear dead.

Fig. 2, is consistent with a continuous column of water within the peduncle, as would be found within a single xylem bundle. Once one of these bundles was nucleated, ice could propagate from its juncture with the xylem vessels in the stem to the distal end of the peduncle, initially bypassing the xylem vessels or bundles in the pedicels attached to the peduncle. Also consistent with this interpretation is the small amount of heat liberated from freezing events such as that depicted in Fig. 2b-d. Fig. 2 suggests that, in at least some peduncles, the individual 'flashes' seen using infrared thermography may be the freezing of xylem vessels, either singly or in small, closely related groups. We observed this complex freezing behavior of individual peduncles in experiments in which the stem sections to which the peduncles were attached were fully hydrated. In the experiments in which stems were air-dried, ice propagation from stem to peduncle occurred more rapidly, in a single event. The rate of this propagation increased as the degree of supercooling of the stem increased.

When cuttings supercooled significantly before ice formed in stems, propagation of ice into floral tissue followed almost immediately, resulting in rapid freezing of all flowers on the cutting. This observation suggests that freezing of stems in woody plants at sub-zero temperatures close to $0^{\circ} \mathrm{C}$ might be advantageous because it would allow maximum supercooling of floral tissues, and that eventual freezing of highly supercooled racemes causes significantly greater damage.

In several of the experiments conducted in Spring 1999, we examined stems and flowers $24 \mathrm{~h}$ after completion of the cooling regimes. We noted an almost perfect agreement between the number of flowers frozen and the number of flowers that were dead $24 \mathrm{~h}$ later (Fig. 5). The cooling regime in these experiments extended to $-5^{\circ} \mathrm{C}$ and included a $60 \mathrm{~min}$ hold at $-5^{\circ} \mathrm{C}$, prior to warming to $+4^{\circ} \mathrm{C}$. As in the experiments carried out the previous year, we observed flowers freezing over a broad

Table 1. Summary of observations of freezing events in blackcurrant stems, leaves, and floral tissues.

\begin{tabular}{|c|c|c|c|}
\hline Tissue & $\begin{array}{l}\text { Freezing } \\
\text { range, }{ }^{\circ} \mathrm{C}\end{array}$ & $\begin{array}{l}\text { No. of } \\
\text { events }\end{array}$ & Comments \\
\hline Stem & -0.5 to -2.0 & 1 & Fully hydrated. \\
\hline Stem & -2.0 to -3.9 & 1 & $\begin{array}{l}\text { Air-dried various lengths of time. Single event propagates } \\
\text { rapidly within stem and directly into attached leaves; ice } \\
\text { nucleation temperature affected by level of hydration. }\end{array}$ \\
\hline Leaf & -0.5 to -3.9 & 1 & $\begin{array}{l}\text { Ice propagated from stem into leaf as soon as ice front reached } \\
\text { leaf petiole. }\end{array}$ \\
\hline Peduncle & -1.3 to -2.2 & 2 to 5 & $\begin{array}{l}\text { Multiple freezing events seen in peduncles on } 10 \text { fully hydrated } \\
\text { stems in } 8 \text { trials. Freezing independent of stem freezing. }\end{array}$ \\
\hline Peduncle & -2.5 to -3.4 & 1 & $\begin{array}{l}\text { Peduncles on } 10 \text { air-dried stems in } 3 \text { trials. Freezing related to } \\
\text { stem freezing. }\end{array}$ \\
\hline Pedicel & -1.6 to -5.5 & 1 or 2 & Initial small freezing event followed by larger freezing event. \\
\hline Flower & -1.6 to -5.5 & 1 & Induced by initial freezing event in pedicel. \\
\hline
\end{tabular}

temperature range. In these experiments that range extended from $-1.6^{\circ}$ to $-5^{\circ} \mathrm{C}$. The cause of the death of the flowers cannot be precisely determined in these experiments; those that froze above $-5^{\circ} \mathrm{C}$ could have been lethally injured when they froze, or they could have been killed during the subsequent cooling to $5^{\circ} \mathrm{C}$.

Although detached flowers can survive being frozen to $-5{ }^{\circ} \mathrm{C}$ if supercooling is prevented (Carter et al., 1999) the present work demonstrates that blackcurrant flowers on intact plants routinely supercool before they freeze, sometimes to temperatures below $-5{ }^{\circ} \mathrm{C}$. Our data do not allow us to conclude that the freezing of a supercooled flower above $-5^{\circ} \mathrm{C}$ is lethal. We suspect that a threshold temperature exists above $-5{ }^{\circ} \mathrm{C}$ and that if a supercooled flower freezes below this threshold it will be killed by the freeze, even though it never reaches $-5^{\circ} \mathrm{C}$. The highest temperature at which a flower was observed to freeze in these experiments was $-1.6^{\circ} \mathrm{C}$, and in all but two of the experiments the temperature at which the first flower on a raceme froze was at or below $-2.0^{\circ} \mathrm{C}$. The existence of such a threshold temperature would help explain the frequently made field observation that spring freezes kill many blackcurrant flowers even when the temperature does not drop to $-5^{\circ} \mathrm{C}$.
Even flowers that remain supercooled throughout a freeze may die if the peduncle to which they are attached is killed. We cannot rule out the possibility that some flowers may supercool to a modest degree, then freeze, and still survive. On intact plants, however, most flowers that survive a freeze apparently do so by remaining supercooled throughout the episode, and are attached to peduncles that are not killed.

The present results explain a puzzling field observation: following a freeze one can often find racemes that contain both living and dead flowers. For example, in Fig. 5b both living and dead flowers are on the raceme in the foreground; also see Fig. 1a of Carter et al. (1999). The observation that pedicels and peduncles are no more freeze-tolerant than are flowers (Carter et al., 1999), suggested that ice initiated in some flowers but did not propagate to the peduncle and thereby to other flowers. Instead, our present results suggest that ice can propagate from stem to flower through the vasculature of a raceme, without causing living cells within the peduncle, or all flowers on that raceme, to freeze. Barriers to ice movement appear to exist at defined anatomical points within racemes, notably at the junctions of stem and peduncle, peduncle/pedicel, and pedicel/ flower. 
All the cultivars used in these experiments responded similarly to freezing. Clear genotypic differences have been observed, however, in the response to freezing of whole blackcurrant plants in controlled-environment and field experiments. The basis of such genotypic variation may be the durability of the barriers to ice movement, and the phenological development and breakdown of these barriers during the acclimation and deacclimation periods occurring in fall and spring, respectively.

\section{Literature Cited}

Ashworth, E.N., D.J. Rowse, and L.A. Billmyer. 1983. The freezing of water in woody tissues of apricot and peach and the relationship to freezing injury., J. Amer. Soc. Hort. Sci. 108:299-303.

Brennan, R.M. 1991. The effect of simulated frost on blackcurrant (Ribes nigrum L.). J. Hort. Sci. 66:607-612.

Brennan, R.M. 1996. Currants and gooseberries, p. 191-295. In: J. Janick and J.N. Moore (eds.). Fruit breeding, vol. II. Vine and small fruits. Wiley, New York.

Brennan, R.M., J.A. Chudek, B.A. Goodman, E.J. Simpson, and G. Hunter. 1997. Non-destructive visualisation in three dimensions of freezing events in flowers of blackcurrant (Ribes nigrum L.) using spin-echo NMR microscopy. 1997. Magnetic Resonance Imaging 15:1085-1090.

Carter, J.V., R. Brennan, and M. Wisniewski. 1999. Low-temperature tolerance of blackcurrant flowers. HortScience 34:855-859.
Dale, A. 1981. The tolerance of blackcurrant flowers to induced frosts. Ann. Appl. Biol. 99:99106.

Dale, A. 1987. Some studies in spring frost tolerance in black currant (Ribes nigrum L.) Euphytica 36:775-781.

Fuller, M.P. and M. Wisniewski. 1998. The use of infrared thermal imaging in the study of ice nucleation and freezing of plants. J. Thermal Biol. 23:81-89.

Lindstrom, O.M. and J.V. Carter. 1983. Assessment of freezing injury of cold-hardened undercooled leaves of Solanum comersonii. Cryo-letters 4:361-370.

Wisniewski, M., S.E. Lindow, and E.N. Ashworth 1997. Observations of ice nucleation and propagation in plants using infrared video thermography. Plant Physiol. 113:327-334. 